\title{
ÇOK ÖLÇÜTLÜ KARAR VERME YÖNTEMLERİ İLE İŞLEME MERKEZİ SEÇIMİ: İMALAT İSLETMESINDE UYGULAMA
}

\author{
Emre YAZICI ${ }^{1}$, Tamer EREN ${ }^{2}$, Hacı Mehmet ALAKAŞ ${ }^{*}$ \\ ${ }^{1}$ Kırıkkale Üniversitesi, Mühendislik ve Mimarlık Fakültesi, Endüstri Mühendisliği Bölümü, Kırıkkale \\ ORCID No: https://orcid.org/0000-0002-3661-2119 \\ ${ }^{2}$ Kırıkkale Üniversitesi, Mühendislik Fakültesi , Endüstri Mühendisliği, Kırıkkale) \\ ORCID No: http://orcid.org/0000-0001-5282-3138 \\ ${ }^{3}$ Kırıkkale Üniversitesi, Mühendislik ve Mimarlık Fakültesi, Endüstri Mühendisliği Bölümü, Kırıkkale \\ ORCID No: https://orcid.org/0000-0002-9874-7588
}

\begin{tabular}{|c|c|}
\hline Anahtar Kelimeler & Öz \\
\hline $\begin{array}{l}\text { İșleme merkezi seçimi, } \\
\text { Analitik Ağ Süreci, }\end{array}$ & $\begin{array}{l}\text { İșletmeler faaliyetlerini sürdürebilmek için üretim sürecinde işgücü, makine ve } \\
\text { tașıma sistemleri gibi kaynakları kullanmaktadırlar. Üretim sektöründe torna, freze }\end{array}$ \\
\hline PROMETHEE, VIKOR & 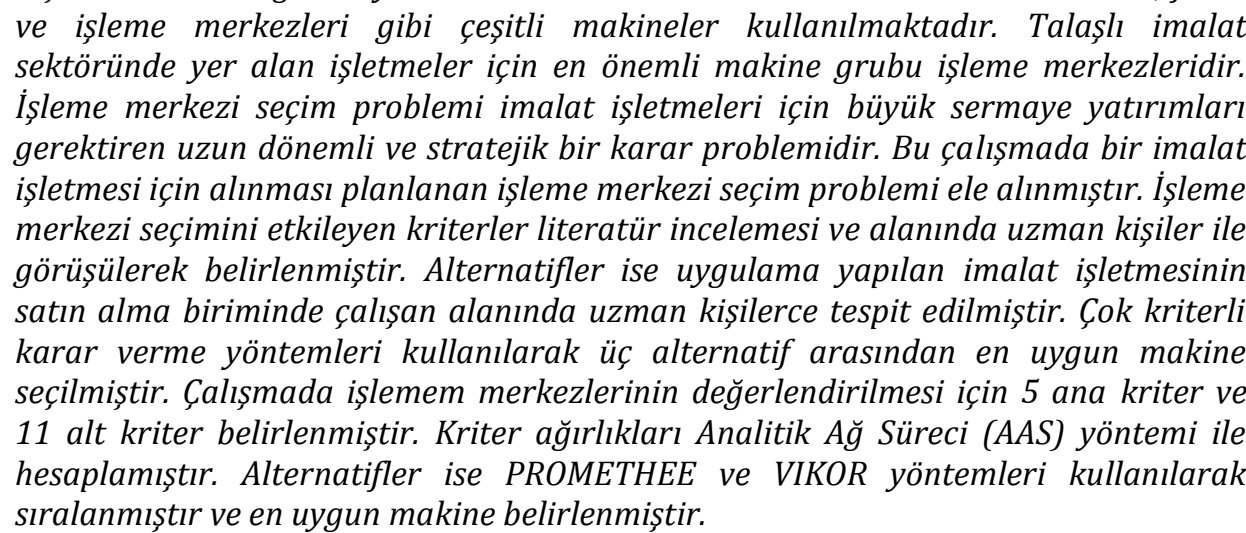 \\
\hline
\end{tabular}

THE MACHINING CENTER SELECTION WITH METHODS OF MULTI CRITERIA MAKING DECISIONS: THE APPLICATION IN MANUFACTURING PLANT

\begin{tabular}{l}
\hline Keywords \\
\hline Machining center selection, \\
Analytic Network Process, \\
PROMETHEE, VIKOR
\end{tabular}

Abstract

Businesses use resources such as labor, machinery, and transportation systems in the production process to carry out their activities. Various machines such as turning, milling and machining centers are used in the production sector. For businesses in the machining sector, the most critical machine group is machining centers. Machining center selection is a long term and strategic decision that requires a high amount of capital investments for manufacturing enterprises. In this study, selecting a machining center planned to be purchased for manufacturing enterprises is examined. The effective criteria for selecting the machining center are determined by the literature review and the interview with experts in this field. Alternatives has been determined by experts from the manufacturing enterprise's procurement unit where the application was made. The number of alternatives was reduced to three by making scoring among the determined alternatives. In this study has been determined five main criteria and eleven sub-criteria. Analytic Network Process (ANP) was used to find the weight of criteria. Two different methods were used to sort and select alternatives, namely PROMETHEE and VIKOR methods.

\begin{tabular}{llll}
\hline Araştırma Makalesi & & Research Article & \\
Başvuru Tarihi & $: 21.08 .2020$ & Submission Date & $: 21.08 .2020$ \\
Kabul Tarihi & $: 06.02 .2021$ & Accepted Date & $: 06.02 .2021$ \\
\hline
\end{tabular}

*Sorumlu yazar; e-posta: $\underline{\text { hmalagas@gmail.com }}$ 


\section{Giriş}

Üretimde sürekliğin sağlanması ve kar etmek işletmelerin temel amaçları arasındadır. Bir sistem olarak işletmelerin çıktıları, girdilerin belirli bir işleme tabi tutulması sonucunda elde edilmektedir. İşlem ise, girdilerde belirli değişiklikler yapılarak girdilerin değerini artıran bir faaliyettir. Günümüzün teknoloji dünyasında özellikle üretim işletmelerinde işlemlerin yerine getirilmesinde makineler ve işleme merkezleri kullanılmaktadır. İmalat işletmelerinde, üretim hızı, üretim kalitesi, verimlilik gibi birçok unsurun üretim sürecinde kullanılan makineler ile doğrudan ilişkisi vardır. Üretim sürecinin esnek olması, imalat işletmelerinde çeşitli özellikteki parçaların işlenebilmesi rekabet ortamında önemli avantajlar sağlamaktadır.

İşleme merkezleri birbirinden farklı özelliklere sahip ürünleri işleme imkanı ile üretimde esneklik sunmaktadır. Bünyesinde barındırdığı takım tezgahları ile metal, plastik, ahşap ve mermer gibi hammaddeleri işleyerek istenilen ürün biçimine getirmektedir (Uyanık, 2006). Bilgisayar destekli tasarım yardımıyla delik açma ve kılavuz çekme gibi operasyonları da yerine getirmektedir (Șahin, 2020). İşleme merkezleri çeşitli yapıdaki iş parçalarını oldukça kısa sürede ve tek bir makinede işleme imkanı sunmakla birlikte sahip olduğu eksen özellikleri ve yetenekleri sayesinde istenen boyutlarda ve spesifikasyon sınırları içerisinde parçaları da işleyebilmektedir (İç ve Yurdakul, 2008). Dolayısıyla doğru işleme merkezi seçimi üretimin kalitesini ve hızını önemli ölçüde artıracaktır. Ancak, yanlış bir seçim ise üretim sürecinde talebin istenilen düzeyde karşılanmaması başta olmak üzere üretim sürecinin olumsuz bir șekilde etkilenmesine neden olacaktır.

Makinelerdeki teknolojik özelliklerin artması ve müşteri taleplerinin çeşitliliği, makine alımına ilişkin karar verme süreçlerinde alternatifleri ve değerlendirme kriterlerini artırmaktadır. Bununla birlikte nicel ve nitel kriterlerin birlikte değerlendirilmesi gerekliliği ortaya çıkmaktadır. İşletmelerin hedeflerine ulaşması için tüm alternatiflerin istenilen kriterlere uygun olarak değerlendirmesi, karar verme sürecini zorlaştırmaktadır. İşleme merkezlerinin seçiminde işlevsel özellikler, işleme kapasitesi, maliyet, servis olanakları ve ekonomik kullanım ömrü gibi kriterler seçim kararını etkilemektedir (Yılmaz, Öztürk, ve Burdurlu, 2017). Piyasada yer alan alternatif işleme merkezleri birbirinden farklı teknik ve mekanik özelliklere sahiptir. Bu durumda işleme merkezi seçimi için dikkate alınan kriterlerin analiz edilerek alternatifler arasından en uygun olanı seçilmelidir. Ancak bu sürecin karmaşı bir yapısı olması nedeniyle karar vericilerin sistemik bir yöntem ile karar vermesi gerekmektedir. Literatürde karar verme sürecinde Çok Kriterli Karar Verme (ÇKKV) yöntemleri yaygın olarak kullanılmaktadır.

ÇKKV yöntemleri makine ve tezgah seçim problemlerinde kullanılan yöntemler arasındadır. ÇKKV yöntemleri alınacak kararlara yönelik olarak kriterlerin değerlendirilmesine ve analizine imkan sağlamaktadır (Kaya, Kılınç, ve Çevikcan, 2007). Bu bağlamda çalışmada işleme merkezi alımı problemi için ÇKKV yöntemleri ile yöneticilere karar desteği sunmak amaçlanmıştır.

$\mathrm{Bu}$ çalışmada bir imalat işletmesi için alınması planlanan işleme merkezi seçim problemi ele alınmıştır. İşleme merkezlerinin müşteri taleplerini karşılamada sağladığı esneklik ve yüksek düzeyde sermaye yatırımı gerektirmesi problemi önemli kılan etmenlerdir. $\mathrm{Bu}$ nedenle işleme merkezi seçimi işletmeler için uzun dönemli stratejik bir karar niteliğindedir. $\mathrm{Bu}$ çalıșma kapsamında uygulamaya konu olan imalat işletmesi atölye tipi üretim yapmakta ve bu yönüyle işleme merkezi seçimi ayrıca bir önem arz etmektedir. Çalıșmada belirlenen kriterlerin birbirlerini etkilemesi ve nicel ve nitel olmak üzere farklı yapıda olmaları nedeniyle problemin çözümünde ÇKKV yöntemleri kullanılmıștır.

Kriterlerin birbiriyle etkileşimi bir ağ yapısı oluşturduğu için kriter ağırlıkları Analitik Ağ Süreci (AAS) yöntemi ile hesaplanmıştır. Alternatiflerin sıralanmasında kriterleri farklı fonksiyon tiplerine göre değerlendirme avantajı sunan PROMETHEE (Preference ranking organization method for enrichment evaluation) yöntemi kullanılmıştır. Çoğunluk için maksimum grup faydasını ve karşıt görüşler için minimum pişmanlığı dikkate alan ve uzlaşık bir çözüm sunarak karar vericilerin fikirlerini daha iyi yansıttı̆̆ından ikinci bir yöntem olarak VIKOR (VIseKriterijumsa Optimizacija I Kompromisno Resenje) yöntemi kullanılmıștır (Paksoy, 2015).

Çalışmanın ikinci bölümünde bilimsel yazın taraması yer almaktadır. Üçüncü bölümde ÇKKV yöntemlerinden AAS, PROMETHEE ve VIKOR yöntemlerinin tanımları ve hesaplama adımları verilmiștir. Dördüncü bölüm, problemin tanımını, 
kriterleri, alternatifleri, ÇKKV yöntemleri ile alternatiflerin değerlendirilmesini içeren uygulamanın yer aldığı bölümdür. Beşinci bölümde ise çalışmanın sonuçları yer almaktadır.

\section{Bilimsel Yazın Taraması}

Bilim yazın taramasında, literatürde yer alan makine, tezgah ve teçhizat seçimi problemini ele alan çalışmalar incelenmiștir. Çalışmaların bir kısmı ÇKKV yöntemleri ile probleme çözüm önerisi sunmuştur. Literatür araştırmasında çalışmalarda kullanılan kriterler ve yöntemler üzerinde durulmuştur. Literatürde yer alan çalışmalarda makine, tezgah ve teçhizat seçimi için dikkate alınan kriterlere ilişkin özet bilgiler Tablo 1'de sunulmaktadır.

Makine seçim problemine yönelik olarak incelenen çalıșmaların tümünde "teknolojik özellik" kriteri dikkate alınmıștır. "Satın alma/kurulum maliyeti" kriterleri çalışmalarda yoğun olarak dikkate alınan bir diğer kriterdir. Bir grup çalışmada teknolojik ve finansal kriterler, "servis hizmetleri" kriterleri ile birlikte değerlendirilmiştir. "Bakım maliyeti" kriteri az sayıda çalıșmada dikkate alınan kriterler arasındadır (Gürbüz ve Uğurlular, 2016; Nouri, Esbouei ve Antucheviciene, 2015).

Makine seçim problemi için finansal kriterler arasında yer alan "ödeme seçenekleri" kriteri yalnızca bir çalışmada dikkate alınmıştır (Kaya ve diğ., 2007). Makinenin fiziksel boyutu ise az sayıda çalışmada dikkate alınan bir diğer kriterdir (Arslan, Çatay, ve Budak, 2004; Dağdeviren, 2008).

$\mathrm{Bu}$ çalışmada dikkate alınan "bütünleyici parça" kriteri Tablo 1'de verilen makine seçimini ele alan çalışmalarda kullanılmamıştır. İşletmelerde fiziksel açıdan değerlendirilen "bütünleyici parça" kriteri aynı zamanda bakım maliyeti gerektiren önemli bir unsurdur. Bu nedenle bu çalıșmada hem fiziksel hem de bakım maliyeti açısından düşünülerek dikkate alınmıştır. Kullanıma ilişkin kriterlere bakıldığında ise "güvenlik" ve yazılım kolaylığı" kriterlerinin Tablo 1'de yer alan çalışmaların çoğunda dikkate alındığı görülmektedir.

Literatürde sağlık (Cihan, Ayan, Eren, Topal ve Yıldırım, 2017), tarım (Tolun ve Tümtürk, 2020), ve gıda (Özdağoğlu, Yakut, ve Bahar, 2017) gibi çeşitli sektörlerde makine seçim probleminin ele alındığ çalıșmalar yer almaktadır. Literatürde yer alan çalışmalarda genel olarak teknolojik ve finansal faktörler dikkate alınarak alternatifler değerlendirmiştir. Bu çalışmada üretim sürecini bütünsel bir yapıda değerlendirilerek satın alma öncesi, makinenin kullanım süreci ve satış sonrası faktörler dikkate alınarak değerlendirilmiştir.

Literatür araștırması kapsamında incelenen çalışmalara Tablo 1'de yer verilmiştir. 
Tablo 1

Makine Seçim Problemini Ele Alan Çalıșmalar ve Dikkate Aldıkları Kriterler

\begin{tabular}{|c|c|c|c|c|c|c|c|c|c|c|c|}
\hline Yazar/Kriterler & İK & EÖ & $\mathrm{BM}$ & KM & ÖS & Tİ & TS & $\mathrm{BP}$ & $\mathrm{H}$ & G & YK \\
\hline Lin ve Yang (1996) & $\checkmark$ & $\checkmark$ & & $\checkmark$ & & & & & & & \\
\hline Arslan ve diğ., (2004) & $\checkmark$ & $\checkmark$ & & $\checkmark$ & & $\checkmark$ & $\checkmark$ & & $\checkmark$ & $\checkmark$ & \\
\hline $\begin{array}{l}\text { Çimren, Çatay ve Budak } \\
\text { (2007) }\end{array}$ & $\checkmark$ & $\checkmark$ & & & & & & & & $\checkmark$ & $\checkmark$ \\
\hline Kaya ve diğ. (2007) & $\checkmark$ & $\checkmark$ & & $\checkmark$ & $\checkmark$ & $\checkmark$ & $\checkmark$ & & & $\checkmark$ & \\
\hline İç ve Yurdakul (2008) & $\checkmark$ & $\checkmark$ & & & & & & & & & \\
\hline Dağdeviren (2008) & $\checkmark$ & $\checkmark$ & & $\checkmark$ & & & & & $\checkmark$ & & \\
\hline Yavuz (2010) & $\checkmark$ & $\checkmark$ & & $\checkmark$ & & & & & & & \\
\hline Perçin (2012) & $\checkmark$ & $\checkmark$ & & $\checkmark$ & & $\checkmark$ & $\checkmark$ & & & $\checkmark$ & $\checkmark$ \\
\hline $\begin{array}{l}\text { Samvedi, Jain ve Chan } \\
\text { (2012) }\end{array}$ & $\checkmark$ & $\checkmark$ & & $\checkmark$ & & $\checkmark$ & $\checkmark$ & & & $\checkmark$ & $\checkmark$ \\
\hline Özdağoğlu (2014) & $\checkmark$ & $\checkmark$ & & & & & & & & & \\
\hline Nouri ve diğ. (2015) & $\checkmark$ & $\checkmark$ & $\checkmark$ & $\checkmark$ & & & & & & $\checkmark$ & $\checkmark$ \\
\hline Wu, Ahmad ve Xu (2016) & $\checkmark$ & $\checkmark$ & & $\checkmark$ & & & & & & & \\
\hline $\begin{array}{l}\text { Karim ve Karmaker } \\
\text { (2016) }\end{array}$ & $\checkmark$ & $\checkmark$ & $\checkmark$ & $\checkmark$ & & $\checkmark$ & $\checkmark$ & & & $\checkmark$ & $\checkmark$ \\
\hline $\begin{array}{l}\text { Gürbüz ve Uğurlular } \\
\text { (2016) }\end{array}$ & $\checkmark$ & $\checkmark$ & $\checkmark$ & $\checkmark$ & & & & & & $\checkmark$ & $\checkmark$ \\
\hline Özdağoğlu ve diğ. (2017) & $\checkmark$ & $\checkmark$ & & $\checkmark$ & & $\checkmark$ & $\checkmark$ & & & & \\
\hline $\begin{array}{l}\text { İç, Kabacaoğlu, Tümay ve } \\
\text { Demirtaş (2018) }\end{array}$ & $\checkmark$ & $\checkmark$ & & & & & & & & & \\
\hline $\begin{array}{l}\text { Li, Wang, Fan, Li ve Chen } \\
(2020)\end{array}$ & $\checkmark$ & $\checkmark$ & & $\checkmark$ & & & & & & & \\
\hline Tolun ve Tümtürk (2020) & $\checkmark$ & $\checkmark$ & & $\checkmark$ & & $\checkmark$ & $\checkmark$ & & & & $\checkmark$ \\
\hline $\begin{array}{l}\text { Bu çalışmada yer alan } \\
\text { kriterler }\end{array}$ & $\checkmark$ & $\checkmark$ & $\checkmark$ & $\checkmark$ & $\checkmark$ & $\checkmark$ & $\checkmark$ & $\checkmark$ & $\checkmark$ & $\checkmark$ & $\checkmark$ \\
\hline
\end{tabular}

İK: İşleme kapasitesi, EÖ: Esneklik özellikleri, BM: Bakım maliyeti, KM: Kurulum maliyeti, ÖS: Ödeme seçenekleri, Tí: Tedarik imkanı, TS: Tedarik süresi, BP: Bütünleyici parça, H: Hacim, G: Güvenlik, YK: Yazılım kolaylığı.

Makine seçimine ilişkin incelenen çalışmalarda kullanılan ÇKKV yöntemleri Tablo 2'de özetlenmektedir. 
Tablo 2

Makine Seçimi için Literatürde Kullanılan ÇKKV Yöntemleri

Yazar

Lin ve Yang (1996)

Arslan ve diğ. (2004)

Çimren ve diğ. (2007)

Kaya ve diğ. (2007)

İç ve Yurdakul (2008)

Dağdeviren (2008)

Yavuz (2010)

Perçin (2012)

Samvedi ve diğ. (2012)

Özdağoğlu (2014)

Nourı ve diğ. (2015)

Wu ve diğ. (2016)

Karim ve Karmaker (2016)

Gürbüz ve Uğurlular (2016)

Özdağoğlu ve diğg. (2017)

İç ve diğ. (2018)

Li ve diğ. (2020)
CKKV Yöntemleri

AHP

ÇKAO

AHP

Bulanık TOPSIS

Bulanık AHP \& TOPSIS

AHP \& PROMETHEE

Aksiyomatik Tasarım

Bulanık AHP \& Bulanık TOPSIS

Bulanık AHP \& GİA

VIKOR \& TOPSIS

Bulanık AAS \& Bulanık TOPSIS

Bulanık VIKOR

AHP \& TOPSIS

AHP

Entropi \& SAW

TOPSIS

Bulanık DEMATEL, Entropi \& VIKOR

AHP \& GİA
Literatürde yer alan makine seçimine ilişkin çalışmalarda Analitik Hiyerarşi Prosesi (AHP) ve TOPSIS yöntemlerinin en yaygin kullanılan yöntemlerdir. Şekil 1'de verilen grafik incelendiğinde AAS, VIKOR, PROMETHEE, Entropi, DEMATEL, Basit Ağırlıklı Toplam (SAW), Gri
İlişkiler Analizi (GİA) yöntemlerinin işleme merkezi veya makine seçim problemlerinde diğer yöntemlere göre literatürde daha az kullanılmıștır. Araştırmacıların tercih ettikleri yöntemlere ilişkin pasta grafiği Şekil 1'de yer almaktadır. 


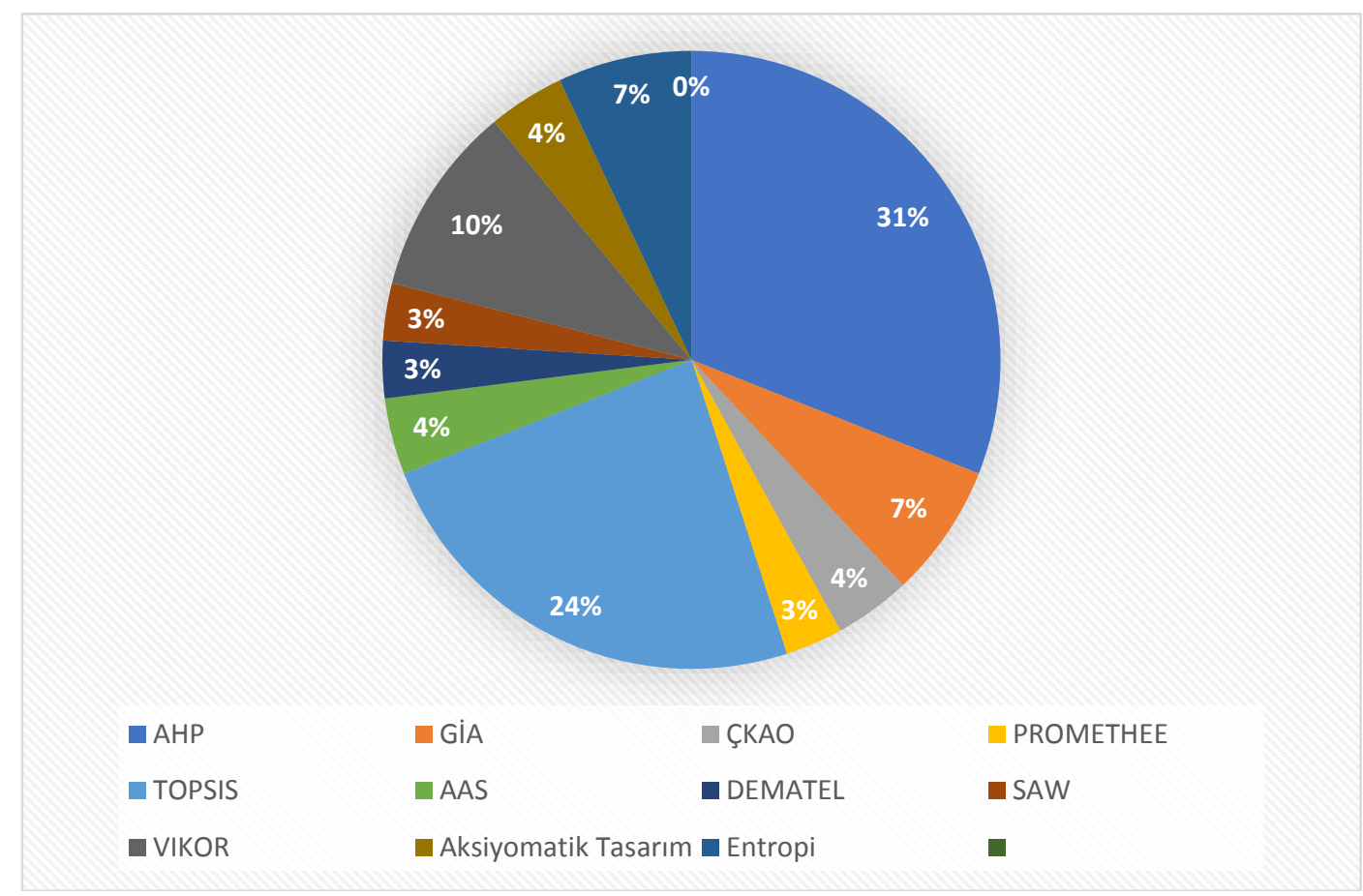

Şekil 1. Makine Seçimi için Literatürde Kullanılan Yöntemlerin Dağılımı

\section{3. Çok Kriterli Karar Verme Yöntemleri}

Karar verme süreci birden fazla alternatif arasından en uygun olanının seçilmesi veya alternatiflerin sıralanmasıdır. $\mathrm{Bu}$ süreçte, karar vericiler kararı hem olumlu yönde hem de olumsuz yönde etkileyen faktörleri bir arada değerlendirilmek zorunda kalabilmektedirler. Aynı zamanda faktörleri değerlendirmede kullanılan skalalar da birbirinden farklı olabilmektedir. Bu nedenle karar vericinin karar sürecinde faktörleri bütüncül değerlendirmeye imkan sağlayan ÇKKV yöntemlerinin kullanılması ile objektif bir karar alınmasını sağlayacaktır.

CKKV yöntemleri nicel veya nitel olarak belirlenen kriterleri dikkate alarak alternatifler arasından karar vericinin en uygun alternatifi belirlenmesi için kullanılmaktadır. Bu çalışmada da giriş bölümünde ifade edilen gerekçeler nedeniyle AAS, PROMETHEE ve VIKOR yöntemleri kullanılmıştır.

\subsection{Analitik Ağ Süreci}

Analitik Ağ Süreci yöntemi, ÇKKV yöntemi olarak Thomas L. Saaty tarafindan literatüre kazandırılmıştır. AAS yöntemi karmaşık karar verme sürecinde kriterler arasında bağımlılık ve geri bildirim içeren ağ yapılarını dikkate almaktadır. AAS yöntemi düşünceyi organize etmeye, duygulara dayalı yargıları ortaya çıkarmaya, onları ölçmeye ve onlardan öncelik elde etmeyi sağlayan ve bütün bunları sentezleyerek matematiksel ve mantıksal sonuca ulaştırmaya yardımcı olan metodolojik bir araçtır (Saaty ve Vargas, 2006).

AAS yönteminde karar verme problemi bir ağ yapısı ile modellenmektedir. Oluşturulan model ile kriterler arası bağımlılıklar ve kriterler arasındaki iç bağımlılıklar dikkate alınmaktadır (Dağdeviren, Dönmez ve Kurt, 2006).

AAS yönteminin adımları Şekil 2'de sunulmaktadır (Hamurcu ve Eren, 2017). 


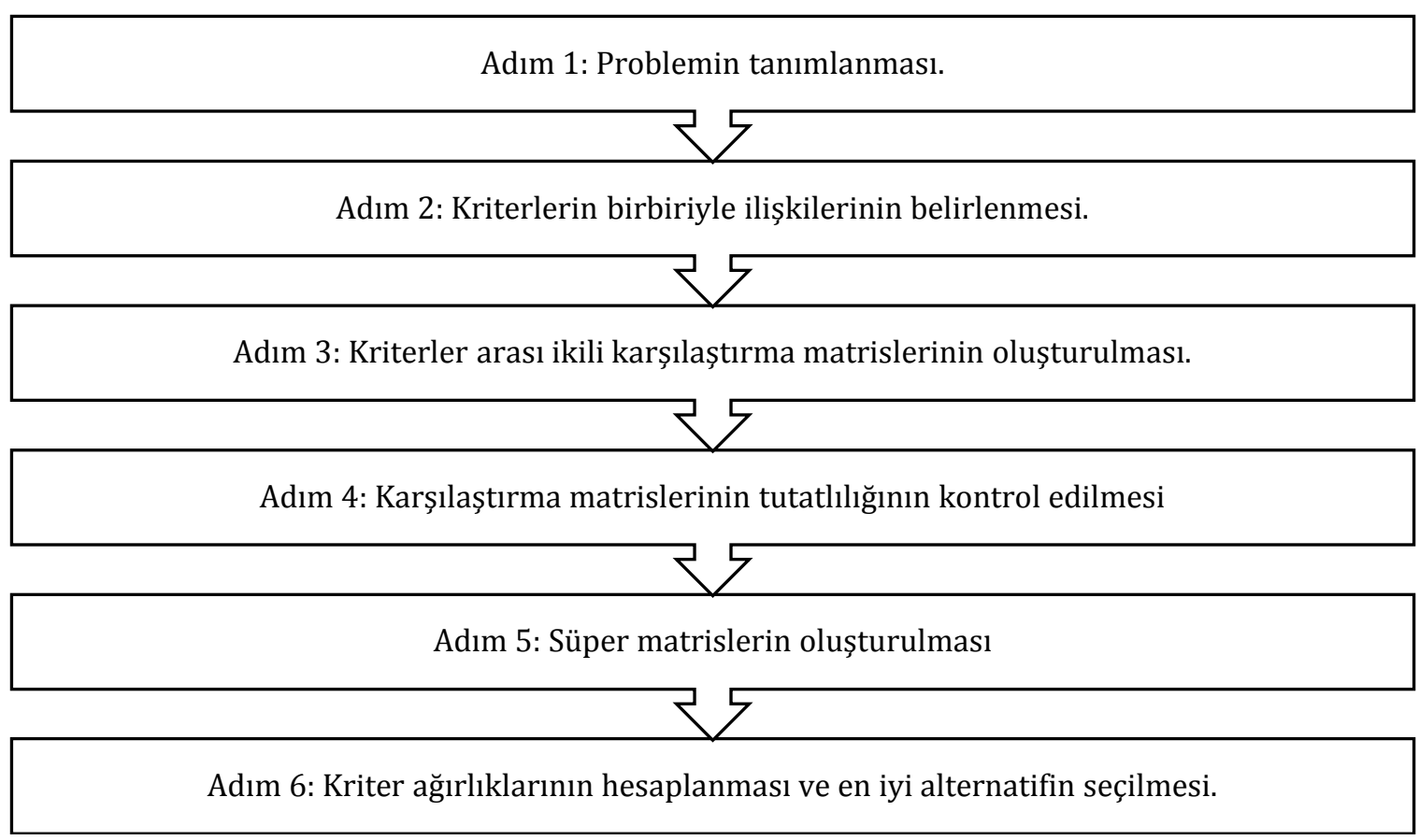

Şekil 2. AAS Yöntemi Adımları

\subsection{PROMETHEE Yöntemi}

PROMETHEE yöntemi Brans (1982) tarafından geliştirilmiş PROMETHEE I ve PROMETHEE II olmak üzere iki temel aşamadan oluşan bir ÇKKV yöntemidir (Şenkayas ve Hekimoğlu, 2013). PROMETHEE yöntemi kısmi sıralama (PROMETHEE I) ve tam siralama (PROMETHEE II) ile karar noktalarının sırasını belirlemektedir. Diğer ÇKKV yöntemlerinden temel farkı değerlendirme kriterlerinin birbiriyle arasındaki ilişki düzeylerini gösteren önem ağırlıklarının yanı sıra değerlendirme kriterlerinin kendi iç ilişkisini de dikkate almasıdır (Bedir ve Eren, 2015).
PROMETHEE yönteminde ilk olarak alternatiflerin farklı kriterlere göre değerlendirildiği sayısal değerler içeren bașlangıç matrisi oluşturulur. Yöntemin uygulanmasında kriterlerin göreceli önem ağırlıkları ve her bir kriter açısından alternatiflerin katkısını karșılaștırmak için karar verici tarafından kullanılan tercih fonksiyonları bilinmelidir (Macharis, Springael, Brucker ve Verbeke, 2020).

PROMETHEE yönteminin uygulama adımları Şekil 3'te sunulan yedi adımdan oluşmaktadır. (Dağdeviren ve Eraslan, 2008). 
Adım 1: Veri matrisinin oluşturulması

Adım 2: Kriterler için tercih fonksiyonlarının tanımlanması.

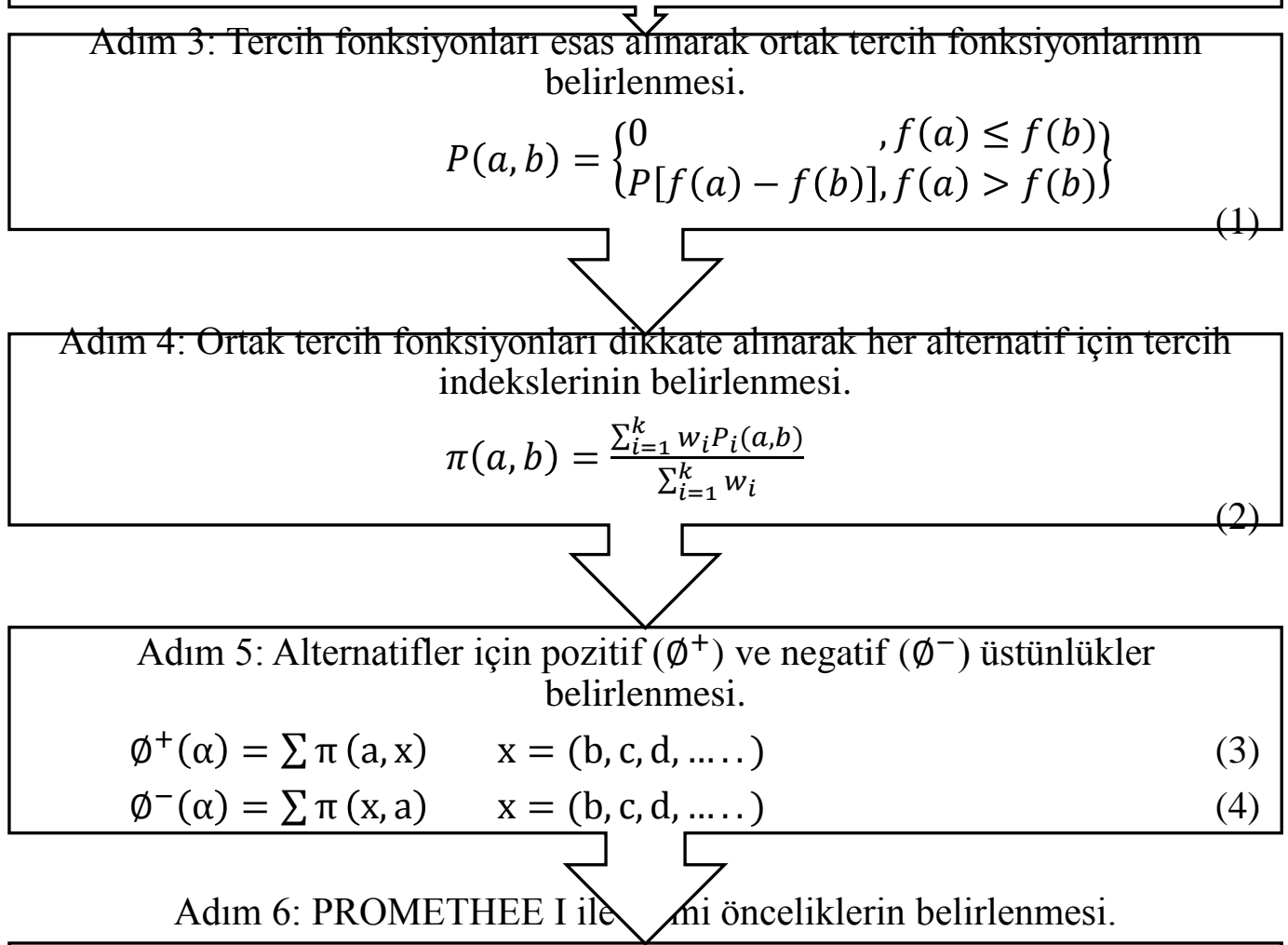

Eşitlik 5, 6 ve 7 herhangi birinin sağlanması ile a alternatifinin $b$ alternatifine tercih edilir.

$$
\begin{aligned}
& \emptyset^{+}(a)>\emptyset^{+}(b) \text { ve } \emptyset^{-}(a)<\emptyset^{-}(b) \\
& \emptyset^{+}(a)>\emptyset^{+}(b) \text { ve } \emptyset^{-}(a)=\emptyset^{-}(b) \\
& \emptyset^{+}(a)=\emptyset^{+}(b) \text { ve } \emptyset^{-}(a)<\emptyset^{-}(b)
\end{aligned}
$$

Eşitlik 8 a alternatifinin $b$ alternatifine üstünlüğü olmadığı durum

$$
\emptyset^{+}(\mathrm{a})=\emptyset^{+}(\mathrm{b}) \text { ve } \emptyset^{-}(\mathrm{a})=\emptyset^{-}(\mathrm{b})
$$

Eşitlik 9 ve 10 a alternatifinin $b$ alternatifi ile karşılaştırılamayacağı durum

$\phi^{+}(\mathrm{a})>\emptyset^{+}(\mathrm{b})$ ve $\emptyset^{-}(\mathrm{a})>\emptyset^{-}(\mathrm{b})$

$$
\emptyset^{+}(a)<\emptyset^{+}(b) \text { ve } \emptyset^{-}(a) \nless \emptyset^{-}(b)
$$

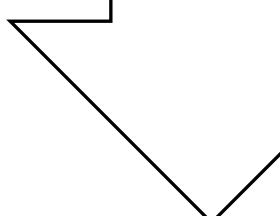

Adım 7: PROMETHEE II ile tam önceliklerin belirlenmesi.

$$
\emptyset(\mathrm{a})=\emptyset^{+}(\mathrm{a})-\emptyset^{-}(\mathrm{a})
$$

Şekil 3. PROMETHEE Yöntemi Adımları 
$\mathrm{Bu}$ adımların uygulanmasında kriterlerin yapısına göre her bir kriter için tercih fonksiyonları belirlenmelidir. PROMETHE yönteminin uygulanması için gerekli olan tercih fonksiyonları Tablo 3'de yer almaktadır (Brans ve Smet, 2016).

Tablo 3

PROMETHEE Yöntemi Tercih Fonksiyonları

Kriter Fonksiyonlar

Tip 1: Olağan Kriter

$$
P(d)= \begin{cases}0 & d \leq 0 \\ 1 & d>0\end{cases}
$$

Tip 2: U Tipi

$$
P(d)=\left\{\begin{array}{l}
0 d \leq q \\
1 d>p
\end{array}\right.
$$

Q
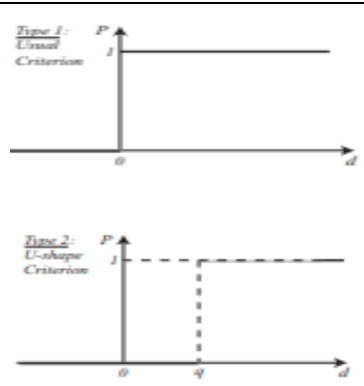

Tip 3: V Tipi

$$
P(d)=\left\{\begin{array}{cl}
0 & d \leq 0 \\
\frac{d}{p} & 0 \leq d \leq p \\
1 & d>p
\end{array}\right.
$$
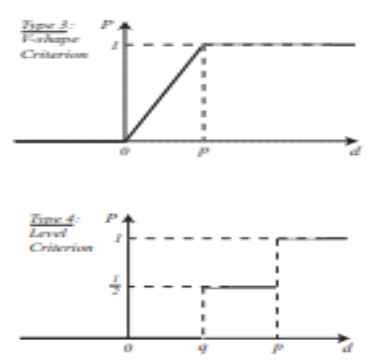

$$
P(d)=\left\{\begin{array}{cc}
0 & d \leq q \\
\frac{1}{2} & q<d \leq p \\
1 & d>p
\end{array}\right.
$$

Tip 5: Doğrusal

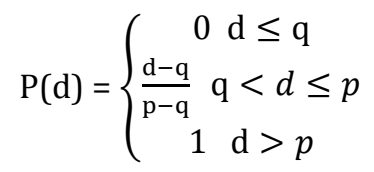

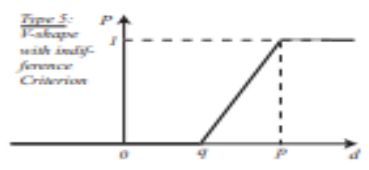

Tip 6: Gaussian

$$
P(d)=\left\{\begin{array}{rl}
0 & d \leq 0 \\
1-e^{-\frac{d^{2}}{2 s^{2}}} & d>0
\end{array}\right.
$$

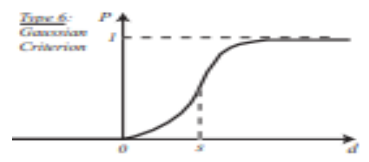

\subsection{VIKOR Yöntemi}

VIKOR yöntemi karmaşık sistemlerde çok kriterli karar verme için Opricovic (1998) tarafından önerilen bir yöntemdir. VIKOR yöntemi, karmaşık yapılarda birbiriyle çelişkili kriterlerin var olduğu karar verme süreçlerinde ayrık bir karar problemini çözmek için geliştirilmiştir. Yöntem çok sayıda alternatif arasından sıralama ve seçim yapmaya odaklanır ve nihai bir karar vermek için karar vericiye yardımcı olur (Opricovic ve Tzeng, 2007).

VIKOR yönteminin adımları Şekil 4'te sunulan beș adımdan oluşmaktadır (Ertuğrul ve Karakaşoğlu, 2009). 
Adım 1: Veri matrisinin oluşturulması ve en iyi ve en kötü değerlerin belirlenmesi.

$$
f_{i}^{*}=\max _{j} f_{i j} \quad f_{i}^{-}=\min _{j} f_{i j} \quad i=1.2 \ldots n
$$

Adım 2: Sj ve Rj değerleri $\mathrm{j}=1,2, \ldots, \mathrm{J}$ için hesaplanır. $\mathrm{Sj}$ ve $\mathrm{Rj}$ değerleri, $\mathrm{j}$. alternatif için ortalama ve en kötü grup skorlarını gösterir.

$$
S_{j}=\sum_{i=1}^{n} w_{i}\left(f_{i}^{*}-f_{i j}\right) /\left(f_{i}^{*}-f_{i}^{-}\right) \text {ve } R_{j}=\operatorname{Max}\left[w_{i}\left(f_{i}^{*}-f_{i j}\right) / f_{i}^{*}-f_{i}^{-}\right]
$$

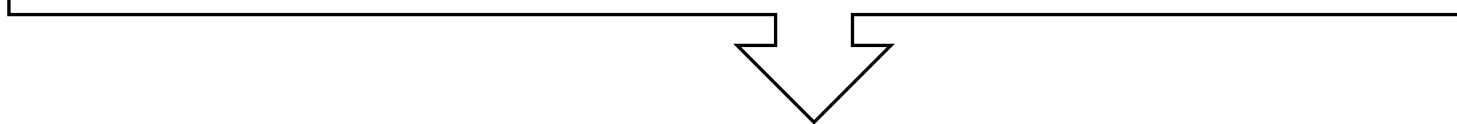

Adım 3: Qj değerleri tüm $\mathrm{j}=1.2 \ldots \mathrm{J}$ için belirlenir.

$$
Q j=v \frac{S j-S^{*}}{S^{-}}-S^{*}+\frac{(1-v)\left(R j-R^{*}\right)}{R^{-}}-R^{*}
$$

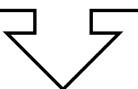

Adım 4: S,R ve Q değerleri küçükten büyüğe doğru sıralanır ve alternatifler arasındaki sıralama tespit edilir.

Adım 5: Kabul edilebilir avantaj ve kabul edilebilir istikrar koșullarının sağlanması ile minimum Q değerine sahip alternatifin en iyi alternatif olarak seçilmesi.

Koşul 1'de Q2-Q1 >= 1/(n-1) durumu sağlanmalıdır

Koşul 2'de ise koşul 1'i sağlayan alternatiflerin S,R ve Q sıralamalarının aynı olması gerekmektedir.

Şekil 4. VIKOR Yöntemi Adımları

VIKOR yönteminin üçüncü adımında $S^{*}=\min S_{\text {J }}$ olarak, $\mathrm{S}^{-}=$max $\mathrm{S}_{\text {J }}$ olarak alınır. $\mathrm{R}^{-}=\max \mathrm{R}_{\mathrm{J}}$ olarak, $\mathrm{R}^{*}=$ min $\mathrm{R}_{\mathrm{J}}$ olarak alınır. $\mathrm{v}$ maksimum grup faydasını temsil eder, 0 ile 1 arasında değer almaktadır. (Opricovic ve Tzeng, 2004).

\section{Uygulama ve Araştırma Metodolojisi}

Çalıșmada bir imalat ișletmesi için alınması planlanan işleme merkezi seçimine yönelik olarak AAS yöntemi ile kriter ağılıkları hesaplanmıştır. Ardından PROMETHEE ve VIKOR yöntemleri ile alternatifler sıralanarak elde edilen sonuçlar karşılaştırılmıştır. Çalışmanın adımları, işleme merkezi seçimi problemin tanımlanması, alternatiflerin ve kriterlerin belirlenmesi, kriter ağırlıklarının elde edilmesi, alternatiflerin sıralanarak en uygun alternatifin seçimi ve sonuçların değerlendirilmesi sürecini kapsamaktadır. Bu süreçler takip edilerek çözülen karar probleminde araştırma ve yayın etiği ilkelerine uyulmuştur. Şekil 5'te çalışmanın uygulama adımları sırasıyla sunulmaktadır. 


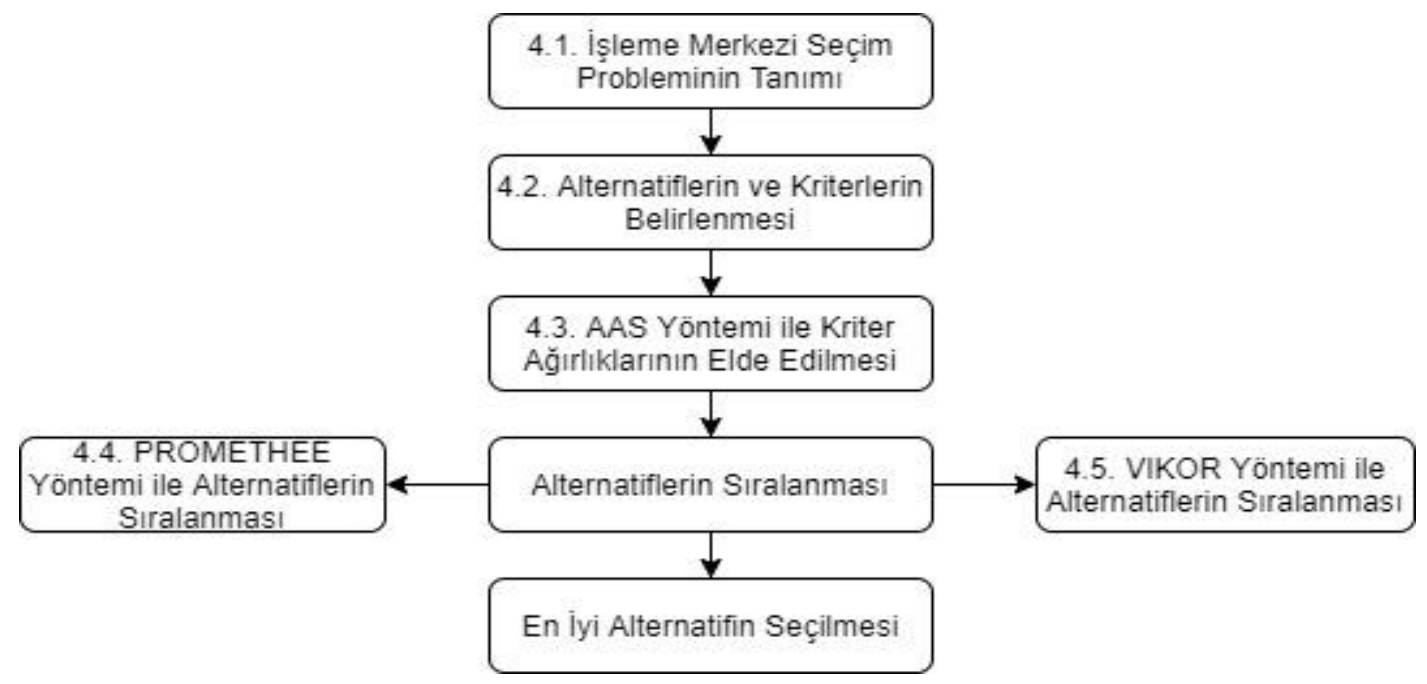

Şekil 5. Araştırma Metodolojisi

Calıșmada problemin tanımlanmasının ardından belirlenen kriterlerin ağırlıkları, AAS yöntemi ile "Super Decisions" paket programı kullanılarak hesaplanmıștır. Hesaplanan kriter ağırlıkları kullanılarak PROMETHEE ve VIKOR yöntemleri ile alternatifler sıralanmıştır ve elde edilen sonuçlar değerlendirilmiștir.

\subsection{Problemin Tanımı}

Bu çalışmada 200'ü aşkın çalışanı bulunan ve yıllık 7 milyon Euro düzeyinde satış potansiyeline sahip bir işletmede işleme merkezi seçim problemi ele alınmıștır. Uygulamaya konu işletmede, müșteri siparişlerine göre çelik ve alüminyum hammadde ile iskele ürünleri, cam çerçevesi, paslanmaz teker üretimi, çelik döküm hammadde ve yarı mamullerin işlenmesinde kullanılmak üzere işleme merkezi alınması planlanmaktadır. İşleme merkezinin alımı için yaklaşık olarak 1.5 milyon TL bütçe ayrılmıștır. İşletmede üretim süreçlerinde işleme merkezleri çokça kullanıldığından üretimin hızı, kalitesi ve verimliliği büyük ölçüde bu makinelere bağlıdır. $\mathrm{Bu}$ bağlamda gerek üretim sürecini doğrudan etkilemesi gerekse yapılacak yatırımın maliyeti açısından işleme merkezinin seçiminde en uygun kararın verilmesi işletme için stratejik nitelikte bir karar problemidir.

\subsection{Alternatiflerin ve Kriterlerin Belirlenmesi}

Alternatifler uygulama yapilan imalat işletmesindeki üst düzey yönetici, satın alma müdürü ve ișleme merkezi operatörleri olmak üzere alanında uzman dört kişi ile bir araya gelerek belirlenmiştir. Alınması planlanan işleme merkezinin üç eksenli $(\mathrm{X}, \mathrm{Y}, \mathrm{Z})$ dikey işleme yeteneğine sahip, minimum 500 milimetre kalınlıkta alüminyum ve çelik hammadde işleyebilen, 10000 devir/dakikanın üzerinde fener mili devrine sahip, fener mili soğutma (30 bar içten soğutma) yapabilme gibi teknik özelliklere sahip olması istenmektedir. Ayrıca kullanım noktasında otomatik arıza gösterme, işleme esnasında müdahale edebilme, harici bellek kullanılabilme ve ağ bağlantısı kurabilme gibi kullanıma ilişkin özellikler barındırması beklenmektedir.

$\mathrm{Bu}$ kapsamda piyasa araştırması neticesinde belirlenen 7 alternatif arasından istenilen minimum özellikleri sağlamayan dört alternatif değerlendirme dışı bırakılarak üç alternatif değerlendirmeye alınmıștır. Bu alternatifler JIH-I CNC 6500 M (A Alternatifi), Frontier MCV 1166 (B Alternatifi), ve TAKUMI (C Alternatifi) markalı işleme merkezleridir. $\mathrm{Bu}$ işleme merkezlerinin piyasa değeri yaklaşık olarak, A alternatifi için 150 Bin Euro, B ve C alternatifi için ise 90 Bin Euro'dur. Kriterler literatürde yer alan çalıșmaların incelenmesi (Arslan ve diğ. 2004; Gürbüz ve Uğurlular 2016; Kaya ve diğ. 2007; Perçin 2012) ve ișleme merkezi seçim konusunda uzman ve tecrübeli, üretim müdürü ve işleme merkezi 
operatörleri ile yapılan mülakatlar neticesinde belirlenmiștir. Belirlenen ana kriterler teknolojik özellik, finansal faktörler, servis faktörleri, fiziksel faktörler ve kullanım faktörleridir. Kriterlere ilișkin bilgiler Tablo 4'te özetlenmiștir.

Tablo 4

Kriterler ve Açıklamaları

\begin{tabular}{|c|c|c|}
\hline Kriterler & Alt Kriterler & Açıklamalar \\
\hline $\begin{array}{l}\text { Teknolojik Özellik } \\
\text { Faktörleri }\end{array}$ & Esneklik Özellikleri (EÖ) & $\begin{array}{l}\text { Tezgahın teknik olarak yeteneklerini } \\
\text { ve esneklik özelliklerini ifade } \\
\text { etmektedir. Ürün işleme kapasitesi, } \\
\text { hız, çeşitli kalınlıktaki malzemelerin } \\
\text { kesimi, eksen sayısı ve takım sayısı vb. } \\
\text { özellikleri değerlendirilmesi. }\end{array}$ \\
\hline Finansal Faktörler & $\begin{array}{l}\text { Bakım Maliyeti (BM) } \\
\text { Kurulum Maliyeti (KM) } \\
\text { Ödeme Seçenekleri (ÖS) }\end{array}$ & $\begin{array}{l}\text { Tezgahın satın alma/kurulum ve } \\
\text { bakım maliyetleri, ve ödeme } \\
\text { seçenekleri }\end{array}$ \\
\hline Servis Faktörleri & $\begin{array}{l}\text { Tedarik İmkanı (Tİ) } \\
\text { Tedarik Süresi (TS) }\end{array}$ & $\begin{array}{l}\text { Tezgahın arızalanması halinde yedek } \\
\text { parça tedarik imkanının kolaylığı ve } \\
\text { tedarik süresi } \\
\text { değerlendirilmesi. }\end{array}$ \\
\hline Fiziksel Faktörler & $\begin{array}{l}\operatorname{Hacim}(\mathrm{H}) \\
\text { Bütünleyici Parça }(\mathrm{BP})\end{array}$ & $\begin{array}{l}\text { Tezgahın tesis alanı içerisinde } \\
\text { kapladığı alan açısından ve bütünleyici } \\
\text { parça varlı̆̆ı } \\
\text { değerlendirilmesi. }\end{array}$ \\
\hline Kullanım Faktörleri & $\begin{array}{l}\text { Güvenlik (G) } \\
\text { Yazılım Kolaylı̆̆ı (YK) }\end{array}$ & $\begin{array}{l}\text { Operatörün tezgahı kullanımı } \\
\text { açısından yazılımında anlaşılırlığı ve } \\
\text { tezgahın kontrolünün güvenlik } \\
\text { açısından değerlendirilmesi. }\end{array}$ \\
\hline
\end{tabular}

\subsection{AAS Yöntemi ile Kriter Ağırlıklarının Elde Edilmesi}

En uygun işleme merkezi seçimini etkileyebilen kriterler bölüm 4.2'de ifade edilmiştir. AAS yöntemine göre kriterlerin öncelik değerlerinin hesaplanması için kriterler arasındaki ilişkiler tanımlanmıştır. AAS yöntemine göre kriter ağırlıklarının elde edilmesinde AAS uygulamaları için geliștirilen "Super Decisions" paket programından yararlanılmıștır (Üstün, Özdemir ve Demirtaş, 2005). AAS yönteminde kriterlerin ilișkileri ve etkileşimleri Şekil 6'da sunulmaktadır. Örneğin teknolojik özellik alt kriterleri kendi arasında ilişkiliyken maliyet ile teknolojik özellik arasında ise tek yönlü bir ilişkinin varlığı belirtilmiştir. Aynı şekilde yedek parça ana kriterinde tedarik imkanı ve tedarik süresi alt kriterlesrinin kendi arasındaki ilișki belirtilmiștir. Kriterler arası ağ yapısı oluşturulduktan sonra AAS yönteminin bir sonraki adımda kriterler birbirleri ile karşılaştırılmıștır. 


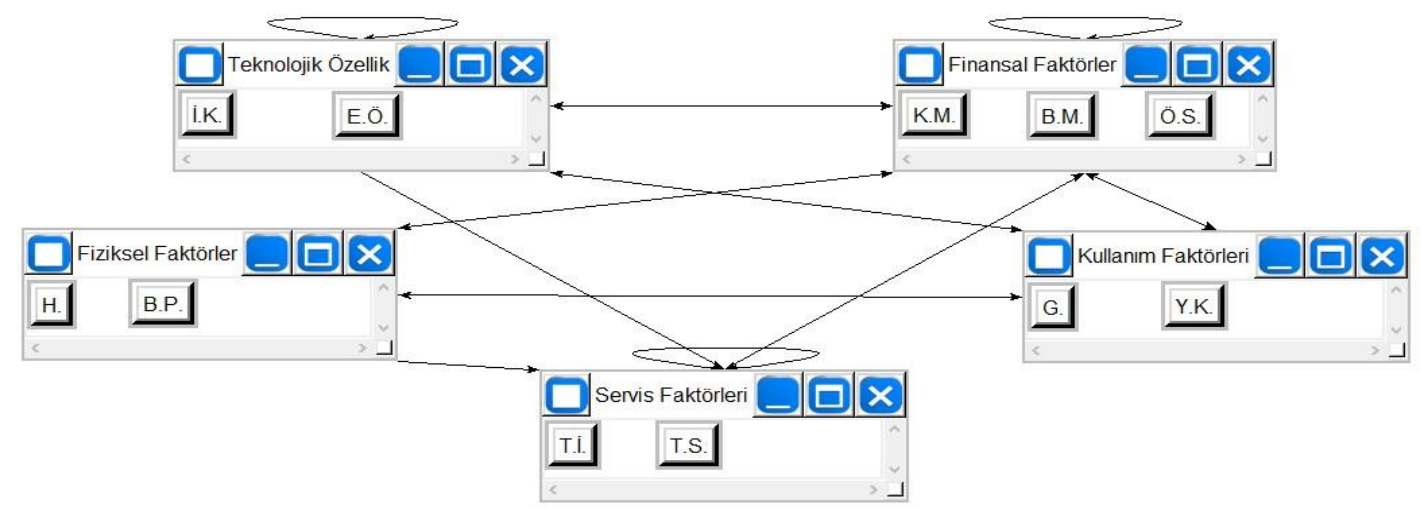

Şekil 6. Kriterler Arası İlișkilerin Gösterimi

Oluşturulan AAS modeli kapsamında kriterlerin birbiri arasındaki karşılaştırmaların yapılmasının ardından "Super Decisions" programı aracılığıyla kriterlerin ağırlıkları elde edilir. İkili karşılaştırma matrislerinde tutarlılı oranları 0,10'un altında çıktığından veriler tutarlıdır. Şekil 7'de "bakım maliyeti" kriterine göre "tedarik imkanı" ve tedarik süresi" kriterlerinin ikili karşılaştırması örnek olarak verilmiștir.

\section{Node comparisons with respect to B.M.}

\section{Graphical Verbal Matrix Questionnaire Direct}

\section{Comparisons wrt "B.M." node in "Servis Faktörleri" cluster}

T.I. is moderately more important than T.S

1. T.i. \begin{tabular}{|l|l|l|l|l|l|l|l|l|l|l|l|l|l|l|l|l|l|l|l|}
$>>9.5$ & 9 & 8 & 7 & 6 & 5 & 4 & 3 & 2 & & 2 & 3 & 4 & 5 & 6 & 7 & 8 & 9 & $>=9.5$ & No comp. \\
\hline
\end{tabular}

Şekil 7. İkili Karşılaştırma Ekranı

Super Decisions paket programı ile elde edilen alt kriter ağırlıkları Şekil 8'de yer almaktadır. AAS yöntemine göre kriterlerin ikili karşılaștırılması neticesinde elde edilen ana kriter ağırlıkları ve alt kriter ağırlıkları Tablo 5'te yer almaktadır. Elde edilen sonuçlara göre teknolojik özellik ve servis kriterlerinin, diğer kriterlere göre daha yüksek düzeyde ağırlığa sahip olduğu görülmektedir. Nitekim işleme merkezinin teknolojik özellikleri işletmeye talepleri karşılayabilme esnekliğini sağlamaktadır. Öte yandan servis imkanlarına kolay ulaşlabilmesi ise işleme merkezinin üretimde daha uzun süre ve verimli kullanılmasını sağlayacaktır. Aksi halde arıza durumunda servis imkanlarına kolay ulaşılamaması işleme merkezinin faaliyetini aksatacaktır. Ana kriterler arasında teknolojik özellik kriteri \%49,82 kriter ağırlığı ile önem düzeyi en yüksek kriterdir. Servis faktörleri \%23,13 kriter ağırlığı ile önem düzeyi yüksek ikinci kriterdir. Bu kriterleri sırasıyla finansal, kullanım ve fiziksel faktörler takip etmektedir. 


\begin{tabular}{|c|c|c|c|c|}
\hline \multicolumn{5}{|c|}{ Here are the priorities. } \\
\hline Icon & Name & $\longdiv { \text { Normalized by Cluster } }$ & $\longdiv { \text { Limiting } }$ & $\hat{\wedge}$ \\
\hline No Icon & B.M. & 0.32263 & 0.094275 & \\
\hline No Icon & K.M. & 0.45717 & 0.133591 & \\
\hline No Icon & ōs. & 0.22020 & 0.064344 & \\
\hline No Icon & B.P. & 0.97619 & 0.032435 & \\
\hline No Icon & $\mathrm{H}$. & 0.02381 & 0.000791 & \\
\hline No Icon & G. & 0.59512 & 0.031442 & \\
\hline No Icon & Y.K. & 0.40488 & 0.021391 & \\
\hline No Icon & T.ì. & 0.50356 & $\longdiv { 0 . 1 4 9 6 4 4 }$ & \\
\hline No Icon & T.S. & 0.49644 & 0.147529 & \\
\hline No Icon & E.O. & 0.55351 & 0.179645 & \\
\hline No Icon & İ.K. & 0.44649 & 0.144913 & Y \\
\hline Okay & opy Values & & & \\
\hline
\end{tabular}

Şekil 8. Super Decisions Programı AAS Sonuçları Ekran Görüntüsü

Tablo 5

AAS Yöntemi Göre Kriter Ağılıkları

\begin{tabular}{lcc} 
Ana Kriterler (Kriter Ağırlıkları) & Alt Kriterler & Alt Kriter Ağırlıkları \\
\hline Teknolojik Özellik (0,49825) & İK & 0,44649 \\
Finansal Faktörler (0,13026) & EÖ & 0,55351 \\
& BM & 0,32263 \\
Servis Faktörleri $(0,23130)$ & KM & 0,45717 \\
Fiziksel Faktörler $(0,06086)$ & ÖS & 0,22020 \\
Kullanım Faktörleri $(0,07933)$ & Tİ & 0,50356 \\
& TS & 0,49644 \\
& BP & 0,97619 \\
& H & 0,02381 \\
\hline
\end{tabular}

\subsection{PROMETHEE Yöntemi ile Alternatiflerin Siralanması}

Çalışmada alternatiflerin sıralamasını elde etmek için "Visual PROMETHEE" paket programı kullanılmıștır. PROMETHEE yönteminin ilk adımı veri matrisi oluşturulmasıdır. Veri matrisinin oluşturulmasının ardından ikinci adımda bölüm 3.2.'de sunulan PROMETHEE tercih fonksiyonları belirlenmelidir. Çalışmada teknolojik özellik, bakım maliyeti ve kurulum maliyeti kriterleri için nicel kriterlere daha uygun olan ve bu üç kriterin özelliklerinin belirli bir ortalamanın üstünde olması istendiği için doğrusal fonksiyon (5. Tip) tercih 
edilmiştir. Herhangi bir tercih ve sınırlamanın söz konusu olmadığı, bütünleyici parça, hacim ve yazılım kolaylığı kriterleri için olağan fonksiyon (1. Tip) kullanılmaktadır (Bülbül ve Köse, 2016). Servis kriterleri ve güvenlik kriterleri için ise $\mathrm{V}$ tipi (3. Tip) fonksiyon kullanılmıştır. Servis ve güvenlik kriterlerinin belli bir değerin üstünde olması gerektiği ancak bu değerlerin altında değere sahip olan alternatiflerin de ihmal edilmesi istenmediği için V tipi (3 Tip) fonksiyon belirlenmiştir (Ömürbek, Karaatll, Eren ve Şanll, 2014).

Karar matrisinin oluşturulması ve ortak tercih fonksiyonlarının belirlenmesinin ardından veriler
"Visual PROMETHEE" programına girilmiștir. Karar matrisinde 1-9 skalası kullanılmıștır. Kriterlerin tanımlanmasının ardından her bir kriter için minimum değerlerin mi yoksa maksimum değerlerin mi karar verici açısından daha iyi olduğu belirtilmiştir. "Max" tanımlanması durumunda veri matrisinde yer alan en büyük değerin karar verici için tercih edilecek değer olacağı, "Min" tanımlanması halinde ise en küçük değerin karar verici için tercih edilecek değer olduğu ifade edilmektedir. Visual PROMETHEE paket programı veri giriş ekranı Şekil 9'da verilmiștir.

\begin{tabular}{|c|c|c|c|c|c|c|c|c|c|c|c|}
\hline Scenario1 & I.K. & E.0. & B.M. & K.M. & o.s. & T.I. & T.S. & B.P. & H. & G. & Y.K. \\
\hline Unit & 9-point & 9-point & 9-point & 9-point & 9-point & 9-point & 9-point & 9-point & 9-point & 9-point & 9-point \\
\hline \multicolumn{12}{|l|}{ Cluster/Group } \\
\hline \multicolumn{12}{|l|}{ Preferences } \\
\hline Min/Max & $\max$ & $\max$ & $\min$ & $\min$ & $\max$ & $\max$ & $\max$ & $\max$ & $\max$ & $\max$ & $\max$ \\
\hline Weight & 0,22 & 0,28 & 0,04 & 0,06 & 0,03 & 0,12 & 0,11 & 0,06 & 0,00 & 0,05 & 0,03 \\
\hline Preference Fn. & Linear & Linear & Linear & Linear & Usual & V-shape & V-shape & Usual & Usual & V-shape & Usual \\
\hline Thresholds & absolute & absolute & absolute & absolute & absolute & absolute & absolute & absolute & absolute & absolute & absolute \\
\hline -Q: Indifference & 4,00 & 4,00 & 5,00 & 5,00 & $n / a$ & $n / a$ & $n / a$ & $n / a$ & $n / a$ & $n / a$ & $n / a$ \\
\hline -P: Preference & 5,00 & 5,00 & 4,00 & 4,00 & $\mathrm{n} / \mathrm{a}$ & 5,00 & 5,00 & $n / a$ & $n / a$ & 5,00 & $n / a$ \\
\hline -S: Gaussian & $\mathrm{n} / \mathrm{a}$ & $n / a$ & $\mathrm{n} / \mathrm{a}$ & $n / a$ & $\mathrm{n} / \mathrm{a}$ & $n / a$ & $n / a$ & $n / a$ & $n / a$ & $n / a$ & $\mathrm{n} / \mathrm{a}$ \\
\hline \multicolumn{12}{|l|}{ Statistics } \\
\hline Minimum & 4,00 & 5,00 & 3,00 & 4,00 & 4,00 & 4,00 & 3,00 & 4,00 & 4,00 & 5,00 & 4,00 \\
\hline Maximum & 7,00 & 7,00 & 6,00 & 6,00 & 6,00 & 5,00 & 5,00 & 7,00 & 7,00 & 7,00 & 5,00 \\
\hline Average & 5,33 & 6,00 & 4,67 & 5,00 & 5,00 & 4,67 & 4,00 & 5,33 & 5,67 & 6,00 & 4,67 \\
\hline Standard Dev. & 1,25 & 0,82 & 1,25 & 0,82 & 0,82 & 0,47 & 0,82 & 1,25 & 1,25 & 0,82 & 0,47 \\
\hline \multicolumn{12}{|l|}{ Evaluations } \\
\hline A Markas & 7,00 & 7,00 & 6,00 & 6,00 & 6,00 & 4,00 & 4,00 & 4,00 & 4,00 & 6,00 & 4,00 \\
\hline B Markası & 5,00 & 5,00 & 5,00 & 4,00 & 4,00 & 5,00 & 5,00 & 5,00 & 6,00 & 5,00 & 5,00 \\
\hline C Markas! & 4,00 & 6,00 & 3,00 & 5,00 & 5,00 & 5,00 & 3,00 & 7,00 & 7,00 & 7,00 & 5,00 \\
\hline
\end{tabular}

Şekil 9. Visual PROMETHEE Veri Giriş Ekranı

Veri girişi ve tercih fonksiyonlarının tanımlanmasının ardından "Visual PROMETHEE" programı ile alternatiflerin sıralaması elde edilmiştir. "Visual PROMETHEE" programı aracıllğlyla pozitif üstünlük $\left(\mathrm{Phi}^{+}\right)$ve negatif üstünlük (Phi-) değerleri hesaplanmıştır. Pozitif üstünlük ve negatif üstünlük değerleri arasındaki fark alınarak tam üstünlük değerleri (Phi) elde edilmiştir. PROMETHEE yöntemine göre alternatiflerin sıralaması Tablo 6'da verilmiștir. $\mathrm{Bu}$ sonuçlara göre C alternatifinin birinci, B alternatifinin ikinci ve A alternatifinin üçüncü alternatif olduğu sonucuna ulaşılmıştır. 
Tablo 6

PROMETHEE Yöntemi Sonuçları

\begin{tabular}{lcccc}
\hline Siralama & Alternatifler & $\mathrm{Phi}^{+}$ & $\mathrm{Phi}^{-}$ & Phi \\
\hline 1 & C & 0,1171 & 0,0488 & 0,0683 \\
2 & B & 0,0926 & 0,0733 & 0,0193 \\
3 & A & 0,0449 & 0,1325 & $-0,0876$ \\
\hline
\end{tabular}

\subsection{VIKOR Yöntemi ile Alternatiflerin Siralanması}

VIKOR yönteminde kullanılan veri matrisi Tablo 7'de yer almaktadır. VIKOR yönteminde de bölüm 4.3'te AAS yöntemi ile hesaplanan kriterlerin ağırlıkları kullanılmıştır. Veri matrisinde yer alan bilgiler ile her kriter için en iyi ve en kötü değerler belirlenmektedir. Burada kriterin maliyeti mi yoksa faydayı mı temsil ettiği önceden bilinmelidir.

Tablo 7

Veri Matrisi

\begin{tabular}{lccccccccccc}
\hline Alternatifler & İK & EÖ & KM & BM & ÖS & TI & TS & BP & H & G & YK \\
\hline A & 7 & 7 & 6 & 6 & 6 & 4 & 4 & 6 & 4 & 6 & 7 \\
B & 5 & 5 & 4 & 5 & 4 & 5 & 5 & 4 & 6 & 5 & 5 \\
C & 4 & 6 & 5 & 3 & 5 & 5 & 3 & 7 & 7 & 7 & 5 \\
En İyi Değer & 7 & 7 & 4 & 3 & 6 & 5 & 5 & 7 & 7 & 7 & 7 \\
En Kötü Değer & 4 & 5 & 6 & 6 & 4 & 4 & 3 & 4 & 4 & 5 & 5 \\
\hline
\end{tabular}

En iyi ve en kötü değerlerin belirlenmesinin ardından VIKOR yöntemi adımları takip edilerek her bir alternatif için $S_{j}$ ve $R_{j}$ değerleri hesaplanır. Ardından $Q_{j}$ değerleri hesaplanmaktadır. $S_{j}$ değeri, en iyi değere olan uzaklıkların toplamını ifade etmektedir. $R_{j}$ değeri ise maksimum uzaklığı temsil etmektedir (Opricovic ve Tzeng, 2007). $Q_{j}$ değerleri hesaplanırken maksimum grup faydasını sağlayan strateji ağırlığını (v) ifade eden bir değer kullanılmaktadır (Paksoy, 2015). Çalışmada 0,25, 0,50 ve 0,75 olmak üzere üç farklı strateji ağırlığına göre $Q_{j}$ değeri hesaplanmıştır. Her bir strateji ağırlığına göre hesaplanan değerler Tablo 8'de verilmiștir.

Tablo 8

Farklı Strateji Ağırlıklarına Göre $Q_{j}$ Sonuçları

\begin{tabular}{lccc}
\hline Alternatifler & $\mathrm{v}=0,25$ & $\mathrm{v}=0,50$ & $\mathrm{v}=0,75$ \\
\hline A & 0 & 0 & 0 \\
B & 1,0957 & 1,1915 & 1,2872 \\
$\mathrm{C}$ & 0,7489 & 0,8326 & 0,9163 \\
\hline
\end{tabular}

Tablo 8'de yer alan sonuçlarda görüldüğü gibi üç farklı strateji ağırlığında da $Q_{j}$ değeri en küçük olan
A alternatifidir. Tablo 9'da $S_{j}, R_{j}$ ve $Q_{j}$ değerleri küçükten büyüğe doğru sıralanmıştır. Elde edilen bu 
değerler ve sıralamalar ile yöntemin son adımı olan kabul edilebilir avantaj ve kabul edilebilir istikrar kümeleri belirlenmektedir.

Tablo 9

$S_{j}, R_{j}$, ve $Q_{j}$ Değerleri ve Siralamaları

\begin{tabular}{lcccccc}
\hline Alternatifler & $S_{\mathrm{j}}$ Değeri & $\mathrm{S}_{\mathrm{j}}$ Sırası & $\mathrm{R}_{\mathrm{j}}$ Değeri & $\mathrm{R}_{\mathrm{j}}$ Sırası & $\mathrm{Q}_{\mathrm{j}}$ Değeri & $\mathrm{Q}_{\mathrm{j}}$ Sırası \\
\hline $\mathrm{A}$ & 0,3919 & 1 & 0,1164 & 1 & 0 & 1 \\
$\mathrm{~B}$ & 0,5680 & 3 & 0,2757 & 3 & 1,1915 & 3 \\
$\mathrm{C}$ & 0,5192 & 2 & 0,2224 & 2 & 0,8326 & 2 \\
\hline
\end{tabular}

A alternatifinin koşul bir ve koşul iki durumunu sağlayarak kabul edilebilir avantaj ve istikrarlı bir avantaja sahip olduğu görülmüştür. Kabul edilebilir avantaj, en iyi ve en iyiye en yakın alternatifi ifade eder. Kabul edilebilir istikrar ise ideal çözüm $\left(Q_{j}\right)$ değerine sahip alternatifin, aynı zamanda en iyi maksimum grup faydası $\left(S_{j}\right)$ veya en iyi minimum pișmanlık $\left(\mathrm{R}_{\mathrm{j}}\right)$ değerlerinden birine sahip olan alternatifi ifade etmektedir (Opricovic ve Tzeng, 2007). VIKOR yöntemine göre ișletme için alınması planlanan alternatifler arasında A alternatifi en iyi alternatif olarak belirlenmiştir. İkinci sırada C alternatifi ve üçüncü olarak ise $B$ alternatifi gelmektedir.

\section{Sonuçlar}

Günümüzde gelișen sanayi teknolojisi ile birlikte imalat sektöründe işletmeler kuruluş sürecinde ve sonraki süreçlerde yüksek sermaye yatırımı gerektiren makineler almaktadırlar. İmalat sanayisinde ihtiyaçların çeşitlenmesi ve teknolojinin gelişmesiyle birlikte makine alımında yöneticilerin daha çok analizler yapmaları gerekmektedir. Farklı kriterlerin etkili olduğu bu süreçte ișletmeler için fazla sayıda alternatifin olması en iyi alternatifin seçimini zorlaştırmaktadır. Bu seçim probleminde yöneticilerin karar verme sürecine yardımcı olmak amacıyla ÇKKV yöntemleri de kullanılmaktadır.

$\mathrm{Bu}$ çalışmada imalat sektöründe faaliyet gösteren bir işletmenin işleme merkezi alım problemi ele alınmıştır. İşletme müşteri taleplerini karşılamada en üst düzeyde fayda sağlayacak, yüksek esneklik düzeyine sahip, servis imkanlarına kolay erișilebilen ve finansal açıdan en uygun ișleme merkezini seçmek istemektedir. Ayrıca seçilecek makinenin işletmenin tesis içi yerleşimine uygun ve personel açısından kullanışlı bir makine olması istenmektedir. $\mathrm{Bu}$ doğrultuda çalışmada işleme merkezi seçimi problemi için kriterler belirlenerek en uygun alternatif ÇKKV yöntemleri kullanılarak belirlemmiştir.

Çalışmada AAS yöntemi ile kriter ağırlıkları hesaplanmıștır. Elde edilen sonuçlara göre, ana kriterlerden teknolojik özellik \%49,82, servis faktörleri $\% 23,13$, finansal faktörler $\% 13,02$, fiziksel özellikler \%6,08 ve kullanım kolaylığı \%7,93 önem düzeyine sahiptir. Bu sonuçlara göre imalat işletmeleri özelinde işleme merkezi alımını etkileyen kriterlerden finansal faktörlerin, teknolojik özellik ve servis faktörlerine göre önem düzeyi daha düşük çıkmıștır. Günümüzde özellikle rekabet ortamından kaynaklı olarak önceliğin müşteri istek ve taleplerini karşllayabilecek nitelikte ürün üretmek olduğu düşünülecek olursa, teknolojik özellikleri yüksek bir işleme merkezine sahip olmak imalat sektöründe rekabet avantajı oluşturmaktadır. Servis faktörü yönünden ise bir işleme merkezinin üretimde sürekli çalışması için servis imkanlarının yaygın olması istenmektedir. Makinenin arıalanması durumunda servis imkanından hızlı bir șekilde yararlanılamaz ise üretim durur ve müşteri siparişleri gecikir. $\mathrm{Bu}$ durum da müșteri kaybına neden olmaktadır. Özellikle sipariş üzerine çalışan ve stoksuz veya stok düzeyi düşük işletmelerde makinanın durmaması ve siparişlerin gecikmemesi için servis ağı yaygın alternatiflerin tercih edilmesi gerekmektedir. Finansal faktörler açısından sonuçlara bakıldığında ise üç farklı alt kriter dikkate alınarak kriter ağırlıkları elde edilmiștir. Finansal faktörler özelinde bakım maliyeti, satın alma maliyeti ve ödeme seçenekleri kriterlerinin öncelik 
değerleri sırasıyla, \%32,26, \%45,71 ve $\% 22,02$ olarak elde edilmiștir. Literatürde yer alan çalışmaların çoğunda finansal faktörler dikkate alınmıştır. Ancak bakım maliyeti dört çalışmada ve ödeme seçenekleri yalnızca bir çalışmada dikkate alınmıştır. Elde edilen kriter ağırlıklarına bakıldığında bakım maliyeti ve ödeme seçenekleri kriterlerinin ağırlıkları önemli bir düzeydedir. Benzer özelliklere sahip birçok işleme merkezinin fiyatları birbirine yakı ancak ödeme seçeneklerindeki esneklik ve bakım maliyetleri karar verici açısından önemli bir unsur olarak değerlendirilmektedir.

Çalışmada AAS yöntemi ile elde edilen kriter ağırlıkları kullanılarak PROMETHEE ve VIKOR yöntemleri ile alternatifler sıralanmıștır. Her iki yöntem ile elde edilen sonuçlar birbirlerinden farklıdır. PROMETHEE yönteminde $\mathrm{C}$ alternatifi birinci alternatif iken VIKOR yönteminde birinci alternatif olarak A alternatifi çıkmıștır. A alternatifinin teknolojik özellik yönünden $\mathrm{C}$ alternatifinin ise servis faktörleri yönünden güçlü alternatifler olduğu görülmektedir. Bu yönüyle elde edilen sonuçlar anlamlı düzeydedir. PROMETHEE yönteminde $\mathrm{C}$ alternatifin birinci $\mathrm{A}$ alternatifinin üçüncü alternatif olarak belirlenmesinin PROMETHEE yönteminde kullanılan ortak tercih fonksiyonu ve eşik değeri tanımlamaları nedeniyle olabileceği düşünülmektedir.

Makine seçim problemlerinde öncelikle işletmeler üretim tipine uygun alternatifleri belirlemelidir. Özellikle seri ve atölye tipi üretim yapan ișletmelerde üretilen ürünün sayıca fazla ve ürün açısından çeșitliliğinin fazla olması makinelerde ürünlerin tiplerine göre farklı özellikler aranmasına neden olmaktadır. Bu tip üretim süreci ile üretim yapan ișletmelerde makinelerin çalıșma saatleri yüksektir. $\mathrm{Bu}$ nedenle arıza potansiyeli yüksek olduğundan servis faktörleri önem arz etmektedir. Proje tipi vb. üretim süreci ile üretim yapan, havacılık ve savunma sanayi gibi sektörlerde ise üretilen ürünlerin çeșitliliği az, fakat işlemlerin yüksek teknolojik özelliklere sahip makineler ile yapılması gerektiği için makinelerin üretilen ürünlere uygun olması önceliklidir. Sektörler farklı olsa dahi bir makine alım kararının verilmesinde, kararın stratejik öneme sahip olduğu göz önünde bulundurularak yöneticilerin teknolojik özellik açısından yüksek donanıma sahip, servis ağı yaygın olan makinelere odaklanması önerilmektedir. Ayrıca finansal faktörler değerlendirilirken kurulum maliyetlerinin yanı sıra bakım maliyetleri ve ödeme seçenekleri gibi faktörlerin değerlendirmeye dahil edilmesi oldukça önemlidir. Zira ișletmeler için bir maddi duran varlık alımında nakit ödeme seçeneğinden ziyade vadeli veya taksitli ödeme seçenekleri daha tercih sebebi olabilmektedir. Makinenin kullanım noktasında ise, işletmelerin makineyi kullanabilecek yeni personel istihdam etmesine ihtiyaç duymadan mevcut personel ile makineyi kullanılabilmesi istenmektedir. $\mathrm{Bu}$ nedenle, makinelerin personelin kullanımı açısından güvenli ve kolay bir işletme prosedürüne sahip olması gerekmektedir. Özellikle gıda, sanayi, tarım ve sağlık sektörleri için de bu çalışmanın kriterleri ve sonuçları örnek teşkil etmektedir. Çalışmada kullanılan teknolojik özellik kriteri işleme merkezi özelinde değerlendirilmektedir. $\mathrm{Bu}$ nedenle diğer sektörlerde bir makine alım problemi ele alınması halinde teknolojik özellik faktörlerinin sektörün yapısına özgü olarak değerlendirilmesi gerekmektedir. Finansal ve servis faktörleri ise genel olarak herhangi bir sektörde makine alım problemi için dikkate alınabilir. Ayrıca çalışmada kullanılan kriterler arasında kurulan ağ yapısı bu çalışmada incelenen probleme özel olarak oluşturulmuștur. Diğer bir sektör için yapılacak çalışmada ağ yapısı değişebilecektir. Araştırmacıların incelediği sektöre göre ağ yapısını yeniden revize etmesi gerekmektedir.

Çalışmada dikkate alınan kriterler imalat sektöründe yer alan bir işletme için alınması planlanan işleme merkezi seçimi problemi özelinde değerlendirilmiştir. Kriterlerin çeşitli sektörler özelinde değerlendirilerek ÇKKV yöntemlerinin uygulanması sonraki araştırmalar için önerilmektedir. Ayrıca birden fazla alternatifin seçilmesinin söz konusu olduğu durumlarda amaç programlama ve matematiksel model ile problemin çözülebileceği önerilmektedir.

\section{Çıkar Çatışması}

Yazarlar tarafından herhangi bir çıkar çatışması beyan edilmemiștir.

\section{Araştırmacıların Katkısı}

$\mathrm{Bu}$ araştırmada; Emre YAZICI, araştırma probleminin tespiti, önemi ve çözümü noktasında araştırmanın planlanması,; Tamer EREN, bilimsel yayın araştırması, makalenin oluşturulması,; Hacı Mehmet ALAKAŞ, problemin çözümü için kullanılan yöntemlerin belirlenmesi, yöntemlerin uygulanması ve sonuçların değerlendirilmesi konularında katkı 
sağlamışlardır.

\section{Kaynaklar}

Arslan, M. C.., Çatay, B., \& Budak, E. (2004). A decision support system for machine tool selection. Journal of Manufacturing Technology Management, 15(1), 101-109. Doi: https://doi.org/10.1108/09576060410512374

Bedir, N., ve Eren, T. (2015). AHP-PROMETHEE Yöntemleri Entegrasyonu ile Personel Seçim Problemi: Perakende Sektöründe Bir Uygulama. Social Sciences Research Journal, 4(4), 46-58. Doi: https://doi.org/10.21541/apjes.328325

Brans, J-P. (1982) L'ingenierie de la decision: Elaboration d'instruments d'aide a la decision. La Methode PROMETHEE, L'aide à la décision: Nature, Instruments et Perspectives d'Avenir, Université Laval, Québec, 183-213.

Brans, J.-P., \& Smet, Y. De. (2016). PROMETHEE METHODS. Multiple criteria decision analysis, 187-219. Springer. Doi: https://doi.org/ 10.1007/978-1-4939-3094-4

Bülbül, S. E. ve Köse, A. (2016). Türk Sigorta Sektörünün PROMETHEE Yöntemi ile Finansal Performans Analizi. Marmara Üniversitesi İktisadi ve İdari Bilimler Dergisi, 38(1), 187-210. Doi: https://doi.org/10.14780/iibd.29194

Cihan, Ş., Ayan, E., Eren, T., Topal, T., ve Yıldırım, E. K. (2017). Çok Ölçütlü Karar Verme Yöntemleri ile Ekokardiyografi Cihazı Seçiminin Yapılması. Sağllk Bilimleri ve Meslekleri Dergisi, 4(1). Doi: https://doi.org/10.17681/hsp.285651

Çimren, E., Çatay, B., \& Budak, E. (2007). Development of a machine tool selection system using AHP. International Journal of Advanced Manufacturing Technology, 35(3-4), 363-376. Doi: $\quad$ https://doi.org/10.1007/s00170-006$\underline{0714-0}$

Dağdeviren, M. (2008). Decision making in equipment selection: An integrated approach with AHP and PROMETHEE. Journal of Intelligent Manufacturing, 19(4), 397-406. Doi: https://doi.org/10.1007/s10845-008-0091-7

Dağdeviren, M., Dönmez, D., ve Kurt, M. (2006). Bir İşletmede Tedarikçi Değerlendirme Süreci İçin Yeni Bir Model Tasarımı ve Uygulaması. Gazi Üniversitesi Mühendislik Fakültesi Dergisi, 21(2), 247-255. Erişim adresi: https://dergipark.org.tr/tr/pub/gazimmfd/issu e/6668/89359

Dağdeviren, M., ve Eraslan, E. (2008). Promethee siralama yöntemi ile tedarikçí seçimi. Journal of the Faculty of Engineering and Architecture of Gazi University, 23(1), 69-75. Erişim adresi: https://dergipark.org.tr/tr/pub/gazimmfd/issu e/6675/88291

Ertuğrul, İ., ve Karakaşoğlu, N. (2009). Banka Şube Performanslarının VIKOR Yöntemi ile Değerlendirilmesi. Endüstri Mühendisliği Dergisi, 20(1), 19-28. Erişim adresi: https://www1.mmo.org.tr/resimler/dosya ekle r/c4692732b25c1ee ek.pdf

Gürbüz, H., ve Uğurlular, A. (2016). En Uygun CNC Tezgahı Seçiminde Analitik Hiyerarşi Yöntemi Yaklaşımı ve Uygulanması. Paper presented at the meeting of the 7th International Congress on Entrepreneurship (ICE 2016), Kırgızistan. Erişim adresi: $\quad$ https://www.researchgate.net/ publication/308890449

Hamurcu, M., ve Eren, T. (2017). Raylı Sistem Projeleri Kararinda AHS-HP ve AAS-HP Kombinasyonu. Gazi Mühendislik Bilimleri Dergisi, 3(3), 1-13. Erişim adresi: https://dergipark.org.tr/tr/pub/gmbd/issue/31 $\underline{064 / 371820}$

İç, Y. T., Kabacaoğlu, E., Tümay, Ç., ve Demirtaş, H. İ. (2018). Küçük ve Orta Büyüklükteki İşletmeler İçin İşleme Merkezi Seçiminde Kullanılabilecek Bir Karar Destek Sistemi. MAKINA Tasarim ve Imalat Dergisi, 16(2), 71-80. Erişim adresi: https://dergipark.org.tr/tr/pub/matim/issue/4 $\underline{9752 / 474174}$

İç, Y. T., ve Yurdakul, M. (2008). İşleme Merkezi Seçimine Yönelik Bir Karar Destek Sisteminin Geliștirilmesi. Gazi Üniversitesi Mühendislik ve Mimarlık Fakültesi Dergisi, 23(1), 85-95. Erişim adresi:

https://dergipark.org.tr/tr/pub/gazimmfd/issu e/6675/88295

Karim, R., \& Karmaker, C. (2016). Machine Selection by AHP and TOPSIS Methods. American Journal of Industrial Engineering, 4(1), 7-13. Doi: https://doi.org/10.12691/ajie-4-1-2

Kaya, İ., Kılınç, M. S., ve Çevikcan, E. (2007). MakineTechizat Seçim Probleminde Bulanı Karar Verme Süreci. Mühendis ve Makina, 49(576), 814. Erişim adresi: https://www.mmo.org.tr/ sites/default/files/2cec96096d4281b ek.pdf 
Li, H., Wang, W., Fan, L., Li, Q., \& Chen, X. (2020). A novel hybrid MCDM model for machine tool selection using fuzzy DEMATEL, entropy weighting and later defuzzification VIKOR. Applied Soft Computing Journal, 91, 106207. Doi: https://doi.org/10.1016/j.asoc.2020.106207

Lin, Z. C., \& Yang, C. B. (1996). Evaluation of machine selection by the AHP method. Journal of Materials Processing Technology, 57(3-4), 253258. Doi: $\quad$ https://doi.org/10.1016/09240136(95)02076-4

Macharis, C., Springael, J., Brucker, K. De, \& Verbeke, A. (2020). PROMETHEE and AHP: The design of operational synergies in multicriteria analysis. Strengthening PROMETHEE with ideas of AHP. European Journal of Operational Research, 153(2004), 307-317. Doi: https://doi.org/ 10.1016/S0377-2217(03)00153-X

Nouri, F. A., Esbouei, S. K., \& Antucheviciene, J. (2015). A Hybrid MCDM Approach Based on Fuzzy ANP and Fuzzy TOPSIS for Technology Selection. INFORMATICA, 26(3), 369-388. Doi: http://dx.doi.org/10.15388/Informatica.2015.53

Ömürbek, N., Karaatlı, M., Eren, H., ve Şanll, B. (2014). AHP Temelli PROMETHEE Siralama Yöntemi ile Hafif Ticari Araç Seçimi. Süleyman Demirel Üniversitesi İktisadi ve İdari Bilimler Fakültesi Dergisi, 19(4), 47-64. Erişim adresi: https://dergipark.org.tr/tr/pub/sduiibfd/issue/ $\underline{20813 / 222634}$

Opricovic, S. (1998). Multi-criteria optimization of civil engineering systems. (Ph. D Thesis), Faculty of Civil Engineering, Belgrade.

Opricovic, S., \& Tzeng, G.-H. (2004). Compromise solution by MCDM methods: A comparative analysis of VIKOR and TOPSIS. European Journal of Operational Research, 156, 445-455. Doi: https://doi.org/10.1016/S03772217(03)00020-1

Opricovic, S., \& Tzeng, G.-H. (2007). Extended VIKOR method in comparison with outranking methods. European Journal of Operational Research, 178, 514-529. Doi: https://doi.org/10.1016/j.ejor.2006.01.020

Özdağoğlu, A. (2014). Üretim Faaliyetinde Bulunan İşletmeler İçin CNC Torna Tezgahı Alternatiflerinin VIKOR ve TOPSIS Yöntemleri ile Karşılaştırılması. AIBÜ Sosyal Bilimler Enstitüsü Dergisi, 14(2), 37-57. Erişim adresi: https://docplayer.biz.tr/15457605-Uretim- faaliyetinde-bulunan-isletmeler-icin-cnc-tornatezgahi-alternatiflerinin-vikor-ve-topsisyontemleri-ile-karsilastirilmasi.html

Özdağoğlu, A., Yakut, E., ve Bahar, S. (2017). Entropi ve SAW Yöntemlerinin Bütünleștirilmesiyle Bir Süt Ürünleri Fabrikasında Makine Seçimi. Dokuz Eylul Universitesi Iktisadi ve Idari Bilimler Fakültesi Dergisi, 32(1), 341-359. Doi: https://doi.org/10.24988/deuiibf.2017321605

Paksoy, S. (2015). Ülke Göstergelerinin Vikor Yöntemi ile Değerlendirilmesi. Ekonomik ve Sosyal Araştırmalar Dergisi, 11(2), 153-169. Erişim adresi: https://dergipark.org.tr/tr/ pub/esad/issue/38966/456085

Perçin, S. (2012). Bulanik Ahs Ve Topsis Yaklaşımının Makine Teçhizat Seçimine Uygulanması. Ç.Ü. Sosyal Bilimler Enstitüsü Dergisi, 21(1), 169-184. Erişim adresi: https://dergipark.org.tr/tr/pub/cusosbil/issue/ $\underline{4389 / 60337}$

Saaty, T. L., \& Vargas, L. G. (2006). Decision Making with the Analytic Network Process (Second Edu). Springer Science+Business Media. Erişim adresi: https://www.springer.com/gp/book $\not 9781461472780$

Şahin, İ. (2020). CNC Dik İşleme Merkezi Seçiminde Çok Kriterli Karar Verme Yöntemleri. T.C. Maltepe Üniversitesi Lisansüstü Eğitim Enstitüsü, İstanbul.

Samvedi, A., Jain, V., \& Chan, F. T. S. (2012). An integrated approach for machine tool selection using fuzzy analytical hierarchy process and grey relational analysis. International Journal of Production Research, 50(12), 3211-3221. Doi: https://doi.org/10.1080/00207543.2011.560906

Şenkayas, H., ve Hekimoğlu, H. (2013). Çok Kriterli Tedarikçi Seçimi Problemine PROMETHEE Yöntemi Uygulaması. Verimlilik Dergisi, 2, 63-80. Erişim adresi: https://dergipark.org.tr/tr/pub/ verimlilik/issue/21763/233932

Tolun, B. G., ve Tümtürk, A. (2020). AHP ile Bütünleşik Gri İlişkisel Analiz Yöntemi ile Makine Seçimi: Bir Üretim İșletmesinde Uygulama. Yönetim ve Ekonomi: Celal Bayar Üniversitesi Íktisadi ve İdari Bilimler Fakültesi Dergisi, 27(1), 21-34. Doi: https://doi.org/10.18657/yonveek.610281

Üstün, Ö., Özdemir, M. S., ve Demirtaş, E. A. (2005). Kıbrıs Sorunu Çözüm Önerlerini 
Değerlendirmede Analitik Serim Süreci Yaklaşımı. Endüstri Mühendisliği Dergisi, 16(4), 2-13. Erişim adresi: https://www.mmo.org.tr/ sites/default/files/10f760a89db30aa ek.pdf

Uyanık, A. S. (2006). Üç Eksenli Terco Yüzey İșleme Tezgahının Bilgisayar ile Kontrolü. (Yüksek Lisans Tezi), Marmara Üniversitesi Fen Bilimleri Enstitüsü, İstanbul.

Wu, Z., Ahmad, J., \& Xu, J. (2016). A group decision making framework based on fuzzy VIKOR approach for machine tool selection with linguistic information. Applied Soft Computing Journal, 42(C). Doi: https://doi.org/ $\underline{10.1016 / \text { j.asoc. } 2016.02 .007}$
Yavuz, M. (2010). Makina Ekipman Seçimine Aksiyomatik Tasarım Yaklașımı. (Yüksek Lisans Tezi). Marmara Üniversitesi Fen Bilimleri Enstitüsü, İstanbul.

Yılmaz, K., Öztürk, Y., ve Burdurlu, E. (2017). Mobilya Endüstrisi Üretim Süreçlerinde Teknoloji Seçimi: Panel Ebatlama Makinesi Seçimi Örneklemesi. İleri Teknoloji Bilimleri Dergisi, 6(3), 774-785. Doi: https://dergipark.org.tr/tr/pub/duzceitbd/issu e/33124/364584 